Doc. PhDr. Felix Černoch, CSc.

Nezanedbatelné dimenze války i míru:

Ekofilozofie, paxologie

Vojenské rozhledy, 2013, roč. 22 (54), č. 1, s. 41-45, ISSN 1210-3292

\title{
The Dimensions of War and Peace that Can't be Neglected: Ecophilosophy \& Paxology
}

\section{Abstrakt:}

Autor se zabývá některými pojmy, jež byly v posledních letech poněkud opomíjeny. Válka je jedním ze způsobů uskutečňování politiky a je současně jak jejím vlastním produktem, tak i jejím posledním prostředkem. Hypertrofie prostředků vedení soudobých válek navozuje atrofii jejich funkce, a tudíz zároveň i opodstatněnosti. Přesto neprestala být možností, byt' krajní, což z environmentálního hlediska představuje nebezpeči totální devastace životního prostředí. Je zvláštní, že ekologové neorientuji svá protestni hnutí hlavní měrou právě sem. Naopakmnozí z nich považuji válku za jev zákonitý, vyplývající z podstaty člověka i světa čili nepřekonatelný. Je tomu mimo jiné zřejmě i proto, že neexistuje ucelená věda, zabývající se válkou a mírem, tzv. paxologie, tj. teorie jak lze ve světě uchovat mír.

\section{Abstract:}

The author explains some terms being neglected in the last few years. War is one of many ways for implementing policy, but actually it is self-breeding and at the same time its own last source. The hypertrophy of available means for warfare creates the atrophy of its functions and consequently even its reason. War is still an extreme choice, bringing about the danger of total devastation of humane environment. It's strange that environmentalists do not put their protests to this centre of gravity. On the contrary, many of them regard wars as a natural thing, originated in the very nature of humane dispositions. It has its source probably in the fact that there is no self-contained theory dealing with war and peace, the so-called paxology - the theory how peace can be maintained in the world.

\section{Klíčová slova:}

Politika, válka, válčení, mír, uchování míru, paxologie, životní prostředí, ekologie, ekofilozofie, nukleární věk.

Key words:

Politics, war, warfare, peace, maintaining peace, paxology, environment, environmentalism, ecophilosophy, nuclear age. 
Motto: Válka je jeden ze způsobů uskutečňování politiky a je současně jak jejím vlastním produktem, tak i jejím posledním prostředkem.

Jaroslav Javůrek

\section{Prolog}

Před čtyřmi lety jsem se zúčastnil mezinárodní vědecké konference, kterou pod názvem Ekofilozofia včera, dnes a zajtra organizovala Katedra politológie a európskych štúdií Filozofickej fakulty Univerzity Konstantina filozofa v Nitře. Vystoupil jsem na ní se sdělením na téma Válka jako totální devastace životního prostředí. Podtextem se mi stala definice její novodobé rozpornosti, kterou mne inspiroval můj někdejší vysokoškolský i vojenský kolega Jaroslav Javůrek: Atrofie její funkce v di̊sledku hypertrofie prostredků jejího vedení. Svou teorii publikoval ve spisku Válka a politika v „nukleárním věku“, který vydalo Naše vojsko, Praha, roku 1968, v rámci edice Diskuse, polemika, názory. Odtud je ostatně převzato i motto této stati. S ohledem na vývoj světové situace, příznačné apologetikou válek a jejich predikcí, jakož i naléhavostí otázek spojených s ochranou životního prostředí respektive představami o možnostech trvale udržitelného rozvoje lidského společenství, jsem se rozhodl vrátit se k oběma těmto myšlenkám i jejich pramenům. Není konečně náhodným ani to, že právě na platformě tohoto teoretického periodika, Vojenských rozhledů, což zřejmě podrobněji vysvětlovat nemusím.

\section{Replika}

V těsné návaznosti na zmíněnou konferenci o ekofilozofii - pojem uvedený do literatury Jurákem Kučírkem v roce 1995 - dovoluji si začít kritickou glosou na konto názorů vedoucího pořádající katedry, jímž byl doc. PhDr. Ivan Dubnička, Ph.D.

Ve své fundovaně podnětné knize Kultúra a environmentálna kríza, kterou mi před časem osobně věnoval na výraz přátelsky odstartované spolupráce, reprodukuje tučným písmem na straně 246 velice rozšířenou a vžitě tradovanou polopravdu o tom, že „, dejiny l’udstva sú dejinami vojen “. Pokud ale byla válka, musel být i mír. Takový či onaký, delší nebo kratší, před válkou i po ní, prostě byl. Jedno prolínalo druhým. Když ale někdo formuluje mír jako přestávku mezi válkami, pak máme plné právo považovat válku za přerušený mír. Či ne? Když právě on platí za přirozený stav a jeho protipól toliko za výchylku z něj, odklon od normality. Nikoliv naopak.

Jestliže ovšem akceptujeme tezi první, tzn. povýšíme na pravdu tvrzení, že dějiny jsou JEN historií válek, musíme za stejně platnou přijmout i tu druhou, čili redukovat mír na POUHOU přestávku mezi nimi. Co to dále evokuje, kam a k čemu vede. Krom toho, že válka se tím puncuje značkou jevu naprosto normálního, běžného a opodstatněného, vymezujeme ho zároveň, jako lidstvu imanentní, tedy logicky vyvozeně i trvalý, přímo a doslova věčný. O tom ještě později.

\section{Polemika}

V citované publikaci dále čteme - hned na protější straně 247 - druhé tučně tištěné ujištění, že ,,vojny boli vždy vedené za účelom získania zdrojov “. S tím lze z větší části souhlasit. Avšak dopovězme si tu pravdu, nebot’ nejde o to, KDO ji má, leč KOHO má ona. Záleží opět více na tom, CO k jejímu vyjevení a zpřesnění kdo přináší. 
Hlavní organizátor výše uvedené konference na ní pronesl referát, který svým obsahem předurčil mnohé následující a vlastně rozhodujícím způsobem ovlivnil diskuzní atmosféru: Genéza environmentálnej krízy: Pokus o evolucionistickú interpretáciu.

Začněme klíčovou otázkou, nakolik o environmentální krizi vůbec jde? Zda existuje jako reálný jev či pouze virtuální děj? Není náhodou spíše krizí environmentalismu případně environmentalistů? Takže co? Je nebo není? Ano? Ne? Již ze způsobu mého tázání budiž zřejmý př́klon k odpovědi, že nikoliv. Zastávám dokonce prokazatelný názor, že spíše dochází $\mathrm{k}$ intenzivnějšímu prosazování ohledů na životní prostředí v opoře o zasvěcenější východiska. Pominula doba jisté živelnosti, vedená více vášnivou zaníceností než vědecky erudovaným a pragmaticky orientovaným racionalismem. Vždyt' i silně zaujatý zaslepenec musí připustit, že před lety se nevyskytoval ,environmentalismus“ ani jako pouhý pojem, zatímco dnes vykrystalizoval v obor, který podněcuje, ale i funduje široce založené hnutí.

\section{Protesty}

A nyní již k avizovanému tématu, ale zároveň i kritice výše zmiňovaného hnutí. Co tím chci o něm říci, naznačit, vám a jemu vzkázat? K zaměřenosti a obsahu jeho mimořádné agilnosti v podobě hojných protestů. Bouří se takřka proti všemu a všem. Za čistotu lesů, vod a strání, ovzduší, půd i skal, za ekologické zemědělství a hygienu měst, snesitelné prostředí vůbec. Proto také proti Temelínu a možná i Mochovcům, proti Dukovanům o poznání méně, proti Jaslovským Bohunicím snad už skoro ani ne.

Paradoxně vyznívá, proč ne proti jaderným zbraním, když ty jsou daleko nebezpečnější a ničivější? Za jejich zákaz, vývoj, výrobu, zkoušky, distribuci, šíření, proliferaci! Či nejlépe proti jakýmkoliv ozbrojeným dobrodružstvím! Vůči konkrétním agresím i válkám všeobecně! Kdepak jsou ti permanentní demonstranti? Nebo se chtěli pouze zviditelnit? Trvá-li tato jejich potřeba i nadále, pak zrovna tady mají př́iležitost lákavější a současně též užitečnější nad jiné, prospěšnou všem, pro ted' i př́iznivější příští.

\section{Nebezpečí}

Ve hře jsou totiž rizika, která můžeme plným právem považovat nejenom za největší, nýbrž i nejnebezpečnější a nejnaléhavější čili nejriskantnější z hlediska nedocenění již také v dobách míru. Jejich materiální nositelé jsou přece součástí výzbroje a výcviku ozbrojených sil mnoha zemí, přitom nejenom těch, jež mají status velmocenský. Konečně neztrácejme z mysli okřídlené, a hlavně vžité úsloví, jež se kdysi dalo tesat: „Chceš-li mír - připravuj válku!“‘

S tím nelze ani v nejmenším koketovat, natož se snažit žertovat či jinak zlehčovat. Jde přece o vážný prostředek sloužící vážné věci, připomíná ve svém traktátu $O$ válce pruský generál a filozof, profesor válečné akademie Carl von Clausewitz. Tam také vedle své slovutné definice o politické podstatě války dodává, že po vypuknutí se však počíná řídit vlastními zákonitostmi, z nichž zdưraznil jednu snad nejpříznačnější a nejvarovnější: Ve válce nejde o vítězství, ale zničení protivníka!

Promítnuta do dneška, získává ona teze na závažnosti, ale i akutnosti. Potvrzuje se totiž pravda, že se jednou válka stane tak ničivou, až přestane být vůbec možnou! Co k tomu ještě dodat? Snad jen pro dokreslení, že nezáleží na tom, KDO co řekne, jako CO kdo 
řekne. Padni komu padni - ve vědě i realitě, teorii či praxi, která to všechno koneckonců kriteriálně prověřuje. Vývoj tato slova více než potvrdil, když dospěl do situace charakterizované $\mathrm{v}$ podtitulku mého referátu z konference, a zároveň je zmíněn mottem této stati, spolu s přiznáním jeho autorství dnes neprávem opomenutému Jaroslavu Javůrkovi. V čem si zaslouží jeho synteticky dotažené analýzy opakované pozornosti, čím projevují nejen svou životnost, ale opětovně stvrzovanou aktuálnost? Prokazatelně se totiž pořád a nadále stáváme svědky hypertrofie prostředků vedení ozbrojených zápasů, což nastoluje otázku, zda tím vlastně už nedochází k atrofii funkce soudobých válek.

Každý zajisté uzná, že v naznačeném smyslu čas již dozrál. Stačí si pouze uvědomit objemy zbrojních arzenálů, které se udávají v desítkových řádech multiplikačního ekvivalentu zničitelnosti Země i jejích obyvatel. Jak jinak u zbraní hromadného ničení, že?

Zřejmě odtud se začíná odvíjet i programová orientace, proklamovaná Barackem Obamou při jeho pražské návštěvě. Kéž by to jednou vešlo do dějin jako po něm pojmenovaná doktrína!

... A tak dnes jasně a s presvědčením prohlašuji, že Amerika se zavazuje usilovat o mír a bezpečí světa bez jaderných zbraní. Nejsem naivní. Tohoto cíle nebude dosaženo rychle - možná to nebude za mého života. Bude to vyžadovat trpělivost a vytrvalost. Ale nyní musíme také ignorovat hlasy, které nám ř́kají, že svět se nemůže změnit. Musíme trvat na tom, že „ANO, my můžeme“!

Vybráno z projevu prezidenta Spojených států severoamerických Baracka Obamy dne 5. dubna 2009 na Hradčanském náměstí v Praze.

\section{Program}

S ohledem na vyřčená fakta o množství a účinnosti moderních zbraní, tedy rozvoje, ale taktéž rozmachu technologií ,,průmyslu vraždění lidí“, se musíme ztotožnit s tvrzením, že současná válka je vskutku schopna totální devastace nejenom onoho prostředí, v němž se děje. Vždyt' nám vymezený životní prostor je přece nedělitelný! Z toho plyne, že nastolené souvislosti platí důkazně za problém řazený mezi globální.

Nicméně o moc humánnější to není ani u klasického vedení bojů čili nasazení a použití zbraní konvenčních. Příklad bombardování aplikovaného na cíle v bývalé Jugoslávii roku 1999 nás přesvědčil, že na věci se nic nemění ani v podmínkách války prohlašující se za etickou, probíhající pod vysoce vztyčeným praporem humanity a pod záštitou světového společenství či s jeho dodatečným razítkem. Jsou však i doklady novější a další docházejí takřka denně ze všech aktuálně otevřených bojišt', mezi něž nepatř́ jen Irák či Afghánistán.

Dopad na lidské a materiální ztráty se týká se stejnou bolestností také válek lokálních neboli tzv. omezených, jakož i válek občanských. Už jenom proto by se dalo bez nich obejít a ne je omluvně prezentovat coby menší zlo, eventuálně přijatelnost. Uvádí se, že od pádu berlínské zdi resp. komunismu bylo takových konfliktů zaregistrováno více než 120 ! Na jejich konto pak padají cca 2 miliony mrtvol a 40 milionů běženců - utečenců. No není to devastace? A nejen prostředí nýbrž především lidství - humanismu.

\section{Apologetika}

Pádný důvod, proč se s obhajobou takových a podobných praktik důsledně vypořádat a zásadně je odmítnout. Zcela bez skrupulí a ohledů na to, že se samy tváří vědecky 
a snaží opírat o modernizované poznatky biologie, psychologie, ekonomie, demografie. Principiálně nemohou obstát žádné názory, natož ucelené teorie, které se snaží válku ospravedlňovat či dokonce nám ji vysvětlovat jako zákonitý jev, a tím pádem nevyhnutelný děj. Přijmout přitom tvrzení, podle něhož válka vyplývá z podstaty lidské existence nebo přímo člověka jako výraz vrozeného pudu či boje o přežití, značí smírit se s její nepřekonatelností.

Naproti tomu nás je schopen přesvědčit resp. v přesvědčení utvrdit názor, podle něhož jest válka jednoznačně a ryze povahy sociální. Vždyt’ tady nebyla odjakživa, proto nemůže být ani provždycky, tedy věčnou! Všechno, co má historický počátek, musí mít přece i svůj historický konec. Takový je železný zákon dějin. V oněch souřadnicích a toliko v nich - musí být zařazována i posuzována.

\section{Východiska}

Dubničkovo pojetí války ve tvaru organizované agrese má ovšem jisté opodstatnění, pokud se jí zabývá ve spojitosti s úvahami environmentálními, tedy expanzivitou mocných. Znamená to připouštění její sociální dimenze, která je jinak pro ni determinantou kardinální od začátku až do konce. Právě v tomto momentu jsem si dovolil onen pohled svým sdělením poněkud rozšířit, a zároveň o něco posunout setrvačné přístupy směrem ke zvýraznění devastujících důsledků války na pozadí jejích sociálních kořenů.

Těmi se válka historicky vymezuje, čímž je zároveň odmítána věčnost i nevyhnutelnost její existence. Připouští se tak možnost překonat ji, ba přímo požaduje nezbytnost soustředěné a vytrvalé snahy o to, diktované až nesmírnou ničivostí jejích moderních podob. Odtud musí být odvíjen cíleně usilovný boj o společenské vědomí, jež bude toho startérem i motorem. Ale zatím tomu tak není, natož aby se v něm stihlo vítězit. Příčina zpožd’ování spočívá též mimo jiné v upřednostňování pohledu ,válečnického“ před „mírotvorným“. Zřejmě to je dáno i fakticitou vědy o válce, zatímco věda o míru - paxologie - se dosud ani nestačila zrodit, což teprve konstituovat na stejnou úroveň společenské razance, jako dokázal její agresivnější protipól.

\section{Bibliografie:}

ČERNOCH, Felix. Válka jako totální devastace životního prostředí: Atrofie její funkce v důsledku hypertrofie prostředků jejího vedení. Referát na mezinárodní vědecké konferenci na Univerzitě Konstantina Filozofa v Nitře 22. dubna 2009.

DUBNIČKA, Ivan a kol. Ekofilozófia včera, dnes a zajtra. Nitra: FF UKF, 2009, 256 stran, ISBN 978-808094-642-5.

JAVŮREK, Jaroslav. Válka a politika v „nukleárním věku“. Praha: Naše vojsko, 1968, 192 stran, D-0380128. 28-062-68.

NORTON, Anne-Lucie. Myšlenky, které měnily svět. Praha: Albatros, 2003, 516 stran, ISBN 80-0001249-9.

TŮMA, Miroslav. Jaderné odzbrojení. Utopie, nebo projev politického realismu? Praha: ÚMV, 2011, (224 stran, ISBN 978-80-86506-96-8.

Bílá kniha o obraně. Praha: MO ČR, 2011, 168 stran. ISBN 978-80-7278-564-3.

Velká všeobecná encyklopedie. Praha: Euromedia Group, 2010, 1182 stran, ISBN 978-80-86938-94-3. 